\title{
PENGARUH STATUS GIZI, KONSUMSI PANGAN DAN FASILITAS BELAJAR TERHADAP PRESTASI BELAJAR MATEMATIKA
}

\author{
AULIA MASRUROH \\ aulia.m89@gmail.com \\ Program Studi Pendidikan Matematika Fakultas Teknik Matematika dan IPA Universitas \\ Indraprasta PGRI
}

\begin{abstract}
Abstrak. Tujuan penelitian ini adalah untuk mengetahui pengaruh status gizi, konsumsi pangan, dan fasilitas belajar secara bersama-sama terhadap prestasi belajar matematika anak SDN 09 Pagi Jakarta Utara, mengetahui pengaruh status gizi terhadap prestasi belajar matematika anak, mengetahui pengaruh konsumsi pangan terhadap prestasi belajar matematika anak, dan mengetahui pengaruh fasilitas belajar terhadap prestasi belajar matematika anak. Metode penelitian yang digunakan adalah metode survei. Sampel berjumlah 40 anak di kelas 4. Pengumpulan data dilakukan dengan menggunakan teknik penyebaran angket dan teknik tes. Analisis data menggunakan analisis regresi berganda. Uji statistik yang digunakan yaitu uji $\mathrm{F}$ dan uji t. Terdapat pengaruh yang signifikan antara status gizi, konsumsi pangan,dan fasilitas belajar secara bersama-sama terhadap prestasi belajar matematika anak $(\mathrm{p}=0.000)$. Terdapat pengaruh yang signifikan antara status gizi terhadap prestasi belajar matematika anak $(\mathrm{p}=0.025)$. Terdapat pengaruh yang signifikan antara konsumsi pangan terhadap prestasi belajar matematika anak $(\mathrm{p}=0.031)$. Terdapat pengaruh yang signifikan antara fasilitas belajar terhadap prestasi belajar matematika anak $(\mathrm{p}=0.000)$.
\end{abstract}

Kata Kunci: Status Gizi, Konsumsi Pangan, Fasilitas Belajar, Prestasti Belajar Matematika.

\section{PENDAHULUAN}

Pembangunan nasional dewasa ini lebih dititikberatkan pada pembangunan ekonomi dan kualitas sumber daya manusia seutuhnya. Salah satu agenda pembangunan nasional adalah mewujudkan kualitas sumber daya manusia (SDM) yang sehat, cerdas, produktif dan mandiri. Meningkatkan status gizi penduduk merupakan basis pembentukan SDM yang berkualitas. Melaksanakan pemantauan konsumsi dan status gizi penduduk secara berkala menjadi sangat penting untuk mengetahui besaran masalah yang perlu segera ditanggulangi. World Health Organization (WHO) menyatakan bahwa gizi adalah pilar utama dari kesehatan dan kesejahteraan sepanjang siklus kehidupan (Soekirman 2002).

Gizi dikatakan baik apabila terdapat keseimbangan dan keserasian antara pertumbuhan fisik dan perkembangan mental (Almatsier, 2011). Gizi kurang terjadi apabila tubuh mengalami kekurangan satu atau lebih zat-zat gizi esensial yang menyebabkan terjadinya gangguan belajar (learning disabilities), kemampuan bekerja kurang, kesakitan sampai kematian. Status gizi dipengaruhi oleh faktor externaldan faktor internal. Faktor external antara lain: tingkat pendapatan, pendidikan, pekerjaan, dan budaya. Sedangkan faktor internal yang mempengaruhi status gizi antara lain: usia dan kondisi fisik. Gizi secara langsung dipengaruhi oleh konsumsi makanan dan penyakit. Seseorang mendapat makanan yang cukup baik tetapi sering diserang diare atau demam, akhirnya dapat menderita gizi kurang. Jika makanan tidak cukup baik maka kondisi fisik dan daya tahan tubuh (imunity) dapat melemah, sehingga mudah diserang penyakit, kurang nafsu makan dan akhirnya mudah terkena gizi kurang (Soekirman 2002). 
Kecukupan zat gizi merupakan prasyarat yang sangat penting dalam perkembangan manusia, termasuk didalamnyaperkembangan otak. Gizi yang cukup dan memenuhi kebutuhan merupakan determinan utama dalam pertumbuhan dan perkembangan otak dari sejak dalam kandungan, dimana pertumbuhan otak berlangsung sejak dalam kandungan hingga usia 0-5 tahun dan perkembangan otak berlangsung mulai usia 6 tahun-usia dewasa, proses pertumbuhan otak hanya berlangsung hingga usia 5 tahun. Setelah itu, proses pertumbuhan otak akan melambat. Manfaatkan waktu yang sangat terbatas tersebut dengan memberikan asupan gizi dan energi secara rutin dengan asupan gizi dan energi yang seimbang, otak akan menerima rangsangan yang baik untuk terus bekerja secara optimal, terutama untuk mengolah semua informasi yang diperoleh saat beraktivitas Perkembangan dan pertumbuhan otak menentukan bagaimana tingkat kecerdasan manusia. Kecerdasan merupakan satu dari empat faktor internal prestasi belajar seseorang.

Kecerdasan seorang anak tidak hanya ditentukan oleh faktor genetik dan faktor lingkungan berupa stimulasi, melainkan juga faktor gizi atau nutrisi yang sehat dan seimbang dalam makanan sehari-hari (Julianto, 2010). Gizi menjadi penting bagi anak sekolah karena selain dapatmeningkatkan kecerdasan anak juga dapat menunjang pertumbuhan secarafisik dan mental, guna mendukung keadaan tersebut anak sekolahmemerlukan kondisi tubuh yang optimal dan bugar sehingga memerlukanstatus gizi yang baik.Menurut Brown dan Pollit (1996) menyatakan bahwa pengaruh asupan zat gizi terhadap gangguan perkembangan anak melalui menurunnya status gizi. Status gizi yang kurang tersebut akan menimbulkan kerusakan otak, sakit, dan penurunan pertumbuhan fisik. Ketiga keadaan ini akan berpengaruh terhadap perkembangan intelektual. Gangguan perkembangan yang tidak normal antara lain ditandai dengan lambatnya kematangan sel-sel syaraf, lambatnya gerakan motorik, kurangnya kecerdasan dan lambatnya respon sosial.

Kecerdasan setiap orang berbeda-beda, ada yang cepat memahami apa yang dipelajari dan ada juga yang lamban dalam memahami apa yang dipelajari. Kecerdasan setiap orang dapat dilihat dari hasil yang dicapai atau biasa disebut dengan prestasi. Prestasi belajar setiap orang dapat dipengaruhi oleh beberapa faktor antara lain tingkat intelegensi dan fasilitas belajar (Suryabrata, 2005). Pemenuhan fasilitas belajar yang baik dapat mendorong siswa untuk rajin belajar. Fasilitas belajar sangat mempengaruhi prestasi belajar siswa karena pemenuhan fasilitas belajar yang memadai dan lengkap akan mendorong siswa untuk mendapat hasil yang maksimal (Suryabrata, 2005).Berdasarkan pemaparan di atas,peneliti tertarik untuk menganalisispengaruhkonsumsi pangan, status gizi, dan fasilitas belajar terhadap prestasi belajar matematika anak di SDN 09 Pagi Jakarta Utara.

\section{TINJAUAN PUSTAKA}

\section{Prestasi Belajar Matematika}

Kecerdasaan adalah kemampuan belajar disertai kecakapan untuk menyesuaikan diri dengan keadaan yang dihadapinya. Kemampuan ini sangat ditentukan oleh tinggi rendahnya intelegensi yang normal selalu menunjukkan kecakapan sesuai dengan tingkat perkembangan sebaya. Semakin tinggi kemampuan intelegensi seseorang siswa maka semakin besar peluangnya untuk mencapai prestasi yang tinggi. Sebaliknya, semakin rendah kemampuan intelegensi seseorang siswa maka semakin kecil peluangnya untuk mencapai prestasi yang tinggi (Hawadi, 2001). Oleh karena itu, intelegensi yang baik atau kecerdasan yang tinggi merupakan faktor yang sangat penting bagi seorang anak dalam usaha belajar. 
Belajar merupakan suatu perubahan dalam tingkah laku, dimana perubahan itu dapat mengarah kepada tingkah laku yang lebih baik, tetapi dapat juga mengarah kepada tingkah laku yang buruk melalui latihan atau pengalaman. Untuk dapat disebut belajar, maka perubahan tersebut harus relatif mantab, harus merupakan akhir daripada suatu periode waktu yang cukup panjang. Tingkah laku yang mengalami perubahan karena belajar menyangkut berbagai aspek kepribadian baik fisik maupun psikis, seperti perubahan dalam pengertian, berfikir, pemecahan suatu masalah, kecakapan, kebiasaan maupun sikap (Purwanto, 2010). Prestasi belajar adalah suatu bukti keberhasilan belajar atau kemampuan seorang siswa dalam melakukan kegiatan belajarnya sesuai dengan bobot yang dicapainya. Prestasi belajar siswa dapat diukur melalui skor prestasi belajar dari beberapa mata pelajaran. Skor prestasi belajar merupakan hasil yang diwujudkan dalam bentuk angka. Perubahan positif yang terjadi pada diri anak menunjukkan adanya hasil belajar (Winkel, 2005).

Orangtua yang bertanggung jawab akan berusaha memenuhi kebutuhan-kebutuhan anak, baik dari segi fisik seperti makanan, maupun segi psikis seperti kebutuhan akan perkembangan intelektual, melalui pendidikan, perawatan, dan pengasuhan. Hal ini sama dalam proses belajar orangtua perlu memperhatikan ketersediaan sarana dan fasilitas belajar. Sarana dan fasilitas belajar yang umumnya harus dimiliki oleh anak dalam proses belajar meliputi ruang belajar, meja belajar, lampu belajar, buku pelajaran, buku catatan, dan alat tulis.

Tersedianya sarana belajar yang memadai memungkinkan anak dapat belajar dengan baik, sehingga memungkinkan anak mencapai prestasi belajar yang baik. Menurut Darman (1984) dalam (Siregar, 2003) bahwa salah satu faktor yang menentukan prestasi belajar adalah adanya fasilitas belajar yaitu perlengkapan belajar. Apabila kebutuhan dan perlengkapan belajar kurang terpenuhi dapat membawa akibat yang negatif, misal anak tidak bisa belajar dengan baik sehingga sulit diharapkan untuk mencapai prestasi yang tinggi.

Fasilitas belajar dapat mempengaruhi proses belajar seseorang. Kurangnya fasilitas menyebabkan siswa kurang dapat mengaktualisasikan kemampuan dasar yang dimilikinya, sehingga dapat menimbulkan kegagalan dalam prestasi akademiknya. Segala bentuk kegiatan belajar mutlak diperlukan alat-alat tulis. Semakin lengkap alat tulis yang dimilki maka semakin lancar proses belajarnya (Gunarsa dan Gunarsa, 2006).

Fasilitas yang dibutuhkan anak dalam kegiatan belajar meliputi fasilitas fisik dan non fisik. Fasilitas fisik seperti buku-buku pelajaran, alat tulis. Fasilitas non fisik seperti guru les. Suasana yang nyaman juga berpengaruh terhadap timbulnya minat anak untuk belajar. Oleh karena itu penyediaan ruang atau tempat khusus bagi anak untuk belajar sangat penting diperhatikan. Selain sarana dan fasilitas belajar, proses belajarpun harus diperhatikan untuk mencapai prestasi belajar yang baik. Proses belajar adalah seluruh kegiatan belajar yang dilakukan oleh anak baik ketika di sekolah maupun di rumah. Kegiatan belajar yang dilakukan anak misalnya mengerjakan pekerjaan rumah yang diberikan guru, pekerjaan sekolah, mempersiapkan diri sebelum ulangan, membaca buku pelajaran secara teratur dan mencatat semua pelajaran yang diberikan oleh guru (Winkel 2005).

\section{Status Gizi}

Gizi adalah suatu proses organisme menggunakan makanan yang dikonsumsi secara normal melalui proses digesti, absorpsi, transportasi, penyimpanan. Metabolisme dan pengeluaran zat-zat yang tidak digunakan untuk mempertahankan kehidupan, pertumbuhan dan fungsi normal dari organ-organ, serta menghasilkan energi (Supariasa, 2004). Status gizi merupakan keadaan kesehatan sekelompok atau individu yang 
ditentukan dengan derajat kebutuhan fisik akan energi dan zat gizi yang diperoleh dari pangan dan makanan, yang dampak fisiknya dapat diukur secara antropometri (Almatsier, 2011). Jadi status gizi adalah suatu keadaan tubuh yang dapat diukur secara antropometri sebagai akibat dari pemakaian, penyerapan dan penggunaan makanan.

Status gizi rendah disebabkan kurang asupan makanan. Makanan hanya mampu bertahan dalam lambung 6-8 jam, setelah itu lambung kosong karena sari-sari makanan telah diserap dan diedarkan ke seluruh tubuh, maka untuk memenuhi kebutuhannya akan terjadi pemecahan glikogen, sehingga terjadi deplesi jaringan yang kemudian menyebabkan perubahan biokimia, perubahan fungsional dan perubahan anatomis tubuh. Jika hal tersebut berlangsung lama akan menyebabkan glukosa darah ke otak berkurang sehingga anak tidak konsentrasi dalam belajar dan daya ingat rendah sehingga prestasi belajar pun rendah (Soekirman, 2002).

Status gizi akan mempengaruhi tingkat kecerdasan seseorang dan kemampuan seseorang dalam menangkap pelajaran di sekolah, sehingga seseorang yang memiliki status gizi baik akan memiliki daya tangkap yang lebih baik dan dapat memperoleh prestasi yang baik pula di sekolahnya. Sebaliknya jika seseorang memiliki status gizi yang kurang atau lebih akan berdampak pada kecerdasan sehingga kurang optimal dalam menangkap pelajaran di sekolah sehingga prestasi belajar kurang baik (Khomsan, 2004).

WHO (2007) merekomendasikan z-score untuk mengevaluasi data antropometri anak, khususnya di negara berkembang, karena anak yang berada jauh di bawah persentil data acuan dapat diklasifikasikan secara akurat. Penentuan status gizi seseorang diukur dengan menggunakan metode antropometri melalui perhitungan indeks IMT/U. Indeks IMT/U ini digunakan untuk seseorang yang berusia 9-24 tahun berdasarkan nilai $z$-score. Seseorang dikatakan sangat kurus $<-3 \mathrm{SD}$, kurus bila $-3 \mathrm{SD} \leq \mathrm{z}<-2 \mathrm{SD}$, normal bila -2 $\mathrm{SD} \leq \mathrm{z} \leq+2 \mathrm{SD}$, kegemukan bila $+2 \mathrm{SD} \leq \mathrm{z} \leq+3 \mathrm{SD}$, dan obesitas bila $\mathrm{z}>+3 \mathrm{SD}$.

$\mathrm{IMT}=\frac{\text { Berat Badan }(K \mathcal{G})}{\text { Ting }^{i} \text { Badan }}$

\section{Konsumsi Pangan}

Konsumsi pangan merupakan informasi tentang jenis dan jumlah pangan yang dikonsumsi (dimakan) oleh seseorang atau kelompok orang pada waktu tertentu. Batasan ini menunjukkan bahwa konsumsi pangan dapat ditinjau dari aspek jenis pangan dan jumlah pangan yang dikonsumsi. Tujuan mengkonsumsi pangan dalam aspek gizi adalah untuk memperoleh sejumlah zat gizi tertentu yang diperlukan oleh tubuh. Konsumsi pangan berkaitan dengan masalah gizi dan kesehatan, masalah pengupahan (kebutuhan hidup minimal), ukuran kemiskinan, serta perencanaan ketersediaan dan produksi pangan daerah (Hardinsyah et al 2002).

Konsumsi pangan sehari-hari bagi sebagian besar penduduk di negara-negara berkembang dipengaruhi oleh beberapa faktor yaitu: 1) Produksi pangan untuk keperluan rumah tangga, 2) Pengeluaran uang untuk keperluan pangan rumah tangga, 3) Tersedianya pangan yang dipengaruhi oleh produksi dan pengeluaran uang untuk keperluan pangan rumah tangga (Harper et al 1986). Kebutuhan zat gizi akan terjamin pemenuhannya dengan cara mengkonsumsi makanan yang beragam. Konsumsi pangan beragam akan memberikan mutu yang lebih baik daripada makanan yang dikonsumsi secara tunggal atau masing-masing pangan yang menyusunnya, hal ini terjadi karena adanya efek saling mengisi (Suhardjo, 1989).

Makanan yang anak-anak konsumsi sebaiknya mengandung sekurang-kurangnya tiga zat gizi. Jumlah makanan yang mereka butuhkan tergantung pada ukuran tubuh, umur, dan aktivitas tubuhnya. Jika anak-anak hanya menunggu jam makan keluarga, 
anak-anak tersebut sering merasa lapar, ada baiknya anak diberi makanan selingan atau memberi makan dengan frekuensi yang lebih sering (Nasoetion dan Riyadi, 1994).

Kecukupan pangan dapat diukur secara kualitatif maupun kuantitatif. Parameter kualitatif meliputi nilai sosial, ragam jenis, bahan makanan, dan cita rasa, sedangkan parameter kuantitatif adalah komposisi zat gizi. Angka Kecukupan Gizi yang Dianjurkan (AKG) atau Recomended Dietary Allowances (RDA) adalah banyaknya masing-masing zat gizi esensial yang harus dipenuhi dari makanan mencakup hampir semua orang sehat untuk mencegah defisiensi zat gizi. AKG dipengaruhi oleh umur, jenis kelamin, aktivitas, berat badan, tinggi badan, dan genetika (FKMUI, 2009). Berikut ini adalah tabel Tingkat Kecukupan Energi dan zat gizi lainnya.

Tabel 1.Klasifikasi Tingkat Kecukupan Energi dan Zat Gizi lain

\begin{tabular}{ll}
\hline Zat gizi & Klasifikasi Tingkat Kecukupan \\
\hline Energi dan protein & Defisit berat $\leq 70 \%$ kebutuhan \\
& Defisit sedang $70-79 \%$ kebutuhan \\
& Defisit ringan $80-89 \%$ \\
& Normal $90-119 \%$ \\
Vitamin dan mineral & Diatas angka kebutuhan $\geq 120 \%$ \\
& Kurang $\leq 77 \%$ angka kecukupan \\
& Cukup $\geq 77 \%$ angka kecukupan \\
\hline
\end{tabular}

Sumber: Gibson 2005

\section{Metode Pengukuran Konsumsi Makanan}

Penilaian konsumsi makanan adalah salah satu metode yang digunakan dalam penentuan status gizi perorangan atau kelompok (Supariasa, 2004). Berdasarkan jenis data yang diperoleh, maka pengukuran konsumsi makanan menghasilkan dua jenis data konsumsi, yaitu bersifat kualitatif dan kuantitatif. Metode yang bersifat kualitatif biasanya untuk mengetahui frekuensi makan. Frekuensi konsumsi menurut jenis bahan makanan dan menggali informasi tentang kebiasaan makan (food habits) serta cara-cara memperoleh bahan makanan tersebut. Metode kuantitatif dimaksudkan untuk mengetahui jumlah makanan yang dikonsumsi sehingga dapat dihitung konsumsi zat gizi dengan menggunakan Daftar Komposisi Bahan Makanan (DKBM) atau daftar lain yang diperlukan seperti Daftar Ukuran Rumah Tangga (URT), Daftar Konversi Mentah-Masak (DKMM) dan Daftar Penyerapan Minyak (Supariasa, 2004).

\section{Metode Frekuensi Makanan (Food Frequency)}

Metode frekuensi makanan adalah untuk memperoleh data tentang frekuensi konsumsi sejumlah bahan makanan atau makanan jadi selama periode tertentu seperti hari, minggu, bulan, atau tahun. Kelebihan metode frekuensi makanan yaitu: relatif murah, dapat dilakukan sendiri oleh responden, tidak membutuhkan latihan khusus, dapat membantu untuk menjelaskan hubungan antara penyakit dan kebiasaan makan. Sedangkan kekurangannya yaitu: tidak dapat untuk menghitung intake zat gizi sehari, sulit mengembangkan kuesioner pengumpulan data, cukup menjemukan bagi pewawancara, perlu membuat percobaan pendahuluan untuk menentukan jenis bahan makanan yang akan masuk dalam daftar kuesioner, responden harus jujur dan mempunyai motivasi tinggi. Kuesionernya mempunyai dua komponen utama yaitu daftar pangan dan frekuensi penggunaan pangan (Supariasa, 2004). Frekuensi konsumsi pangan dikelompokkan menjadi empat yaitu sering ( $\geq 5$ kali/minggu), kadang-kadang (3-4 kali/minggu), jarang (1-2 kali/minggu), dan tidak pernah (0 kali/minggu). 


\section{Metode Mengingat-ingat (Food Recall Method)}

Prinsipnya metode ini dilakukan dengan cara mencatat jenis dan jumlah bahan yang dikonsumsi pada masa lalu (biasanya 24 jam yang lalu) melalui wawancara. Penaksiran jumlah pangan yang dikonsumsi diawali dengan menanyakan dalam bentuk ukuran rumah tangga (URT) seperti potong, ikat, gelas, piring, atau alat lain yang biasa digunakan di rumah tangga. Selanjutnya dikonversi ke dalam satuan gram. Agar diperoleh hasil yang teliti maka perlu dilatih sebelumnya mengenai penggunaan URT dan mengkonversikannya ke satuan berat (Hardinsyah et al 2002).

Metode ini mempunyai kelemahan dalam tingkat ketelitiannya, karena keterangan-keterangan yang diperoleh adalah hasil ingatan responden. Namun, kelemahan ini dapat diatasi dengan memperpanjang waktu survei (lebih dari 1x24 jam). Kelebihan dari metode ini adalah murah dan sederhana. Metode ini direkomendasikan untuk survei konsumsi pangan dalam rangka memperoleh gambaran (representasi) dari populasi. Metode ini bisa digunakan untuk individu dan keluarga (Hardinsyah et al 2002).

\section{METODE}

Penelitian ini menggunakan pendekatan kuantitatif dengan metode penelitian survei. Penelitian survei ini menggunakan teknik pengamatan atau penyelidikan yang kritis untuk mendapatkan keterangan yang terang dan baik terhadap suatu persoalan tertentu dan didalam suatu daerah tertentu. Penelitian ini menguji pengaruh pola konsumsi pangan, status gizi dan fasilitas belajar terhadap prestasi belajar matematika anak. Variabel bebas (independent variable)dalam penelitian ini adalah pola konsumsi pangan $\left(\mathrm{X}_{1}\right)$, status gizi $\left(\mathrm{X}_{2}\right)$ dengan skala data numerik, dan fasilitas belajar siswa $\left(\mathrm{X}_{3}\right)$ dengan skala data ordinal, sedangkan variabel terikat (dependent variable) adalah prestasi belajar matematika anak (Y) dengan skala numerik. Desain analisis yangdigunakan untuk menguji hubungan antar variabel dalam penelitian ini adalah Analisis Regresi(Regresi Analysis).Desain penelitian ini adalah cross sectional study, dilakukan di SDN 09 Pagi Pademangan Barat Jakarta Utara. Pemilihan lokasi sekolah dasar dilakukan secara purposive yaitu sekolah dasar yang status gizinya beragam. Pemilihan tersebut berdasarkan pertimbangan kemudahan dalam melakukan penelitian. Model hubungan antara keempat variabel penelitian ini dapat digambarkan dalam bentuk konstelasi permasalahan sebagai berikut:

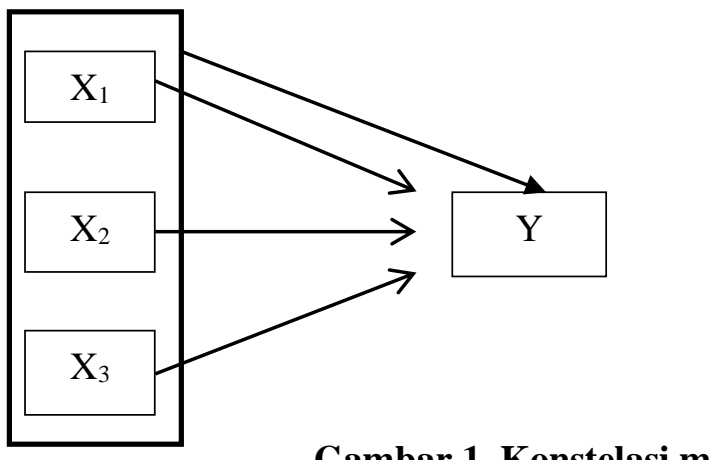

Keterangan:

$\mathrm{X}_{1} \quad$ : Pola Konsumsi Pangan

$\mathrm{X}_{2} \quad$ : Status Gizi

$\mathrm{X}_{3} \quad$ : Fasilitas Belajar

Y :Prestasi Belajar Matematika

\section{Gambar 1. Konstelasi masalah penelitian}

Berdasarkan Gambar 1, tentang konstelasi masalah penelitian menjelaskan bahwa:

1. Terdapat pengaruh status gizi, konsumsi pangan, dan fasilitas belajar secara bersamasama terhadap prestasi belajar matematika anak.

2. Terdapat pengaruh status gizi terhadap prestasi belajar matematika anak.

3. Terdapat pengaruh konsumsi pangan terhadap prestasi belajar matematika anak.

4. Terdapat pengaruh fasilitas belajar terhadap prestasi belajar matematika anak. 


\section{HASIL DAN PEMBAHASAN \\ Analisis Dekriptif Data}

Analisis deskriptif data adalah bagian dari statistic yang digunakan untuk menggambarkan atau mendeskripsikan data. Tabel 2 menggambarkan data penelitian tentang status gizi, konsumsi pangan, fasilitas belajar, dan prestasi belajar.

Tabel 2. Ringkasan Deskripsi Statistik

\section{Descriptive Statistics}

\begin{tabular}{lccccc}
\hline & $\mathrm{N}$ & Minimum & Maximum & Mean & Std. Deviation \\
\hline Statusgizi & 40 & -4.33 & 3.57 & .3138 & 1.70590 \\
\hline Konsumsipangan & 40 & 50.30 & 272.70 & 143.4400 & 43.31564 \\
\hline Fasilitasbelajar & 40 & 50.00 & 97.00 & 75.3000 & 10.10001 \\
\hline Prestasibelajar & 40 & 40.00 & 90.00 & 73.5000 & 11.39050 \\
\hline Valid N (listwise) & 40 & & & & \\
\hline
\end{tabular}

Berdasarkan data diatas, status gizi yang dilakukan terhadap 40 anak dalam penelitian ini, rentangan z-score terletak pada angka minimum dan maksimum -4.33 sampai dengan 3.57. Rentangan ini memberikan gambaran bahwa z-score status gizi terendah mengenai adalah -4.33 (underwheight) sedangkan z-score status gizi tertinggi yaitu 3.57 (obesitas). Selanjutnya mean atau rata-rata status gizi anak sebesar 0.3138. Hal ini menunjukkan bahwa status gizi anak normal.

Data hasil recall konsumsi pangan yang dilakukan terhadap 40 anak dalam penelitian ini, rentangan nilai terletak pada angka minimum dan maksimum 50.30 sampai dengan 272.79. Rentangan ini memberikan gambaran bahwa nilai terendah mengenai konsumsi pangan adalah 50.30 yang menunjukkan bahwa konsumsi pangan anak termasuk kurang, sedangkan nilai maksimumnya adalah 272.79 yang menunjukkan bahwa konsumsi pangan anak termasuk lebih. Selanjutnya nilai mean atau rata-rata konsumsi pangan sebesar 143.44, hal ini menunjukkan bahwa konsumsi pangan anak berkecenderungan positif dan cukup baik.

Data hasil angket fasilitas belajar yang dilakukan terhadap 40 anak dalam penelitian ini, rentangan nilai terletak pada angka minimum dan maksimum 50 sampai dengan 97. Rentangan ini memberikan gambaran bahwa nilai terendah mengenai fasilitas belajar adalah 50 yang menunjukkan bahwa fasilitas belajar anak ini termasuk rendah, sedangkan nilai maksimumnya adalah 97 yang menunjukkan bahwa fasilitas belajar anak ini termasuk tinggi. Selanjutnya nilai mean atau rata-rata fasilitas belajar sebesar 75.30. Hal ini mengindikasikan bahwa fasilitas belajar anak terhadap prestasi belajar matematika cukup baik.

\section{Pengujian Prasyarat Analisis Data}

\section{Uji Normalitas}

Uji normalitas dilakukan untuk mengetahui apakah data yang diperoleh berasal dari populasi berdistribusi norma atau tidak. Hal ini dilakukan sebagai syarat jika pengujian dilakukan dengan menggunakan statistic parametrik. Melakukan uji normalitas dengan menggunakan SPSS 20 yaitu Kolmogorov Smirnov sebagai alat bantu. Jika nilai probabilitas $\mathrm{p}>0.05$, hal ini menunjukkan tolak $\mathrm{H}_{1}$ dan terima $\mathrm{H}_{0}$ maka data berdistribusi normal. 
Tabel 3. Ringkasan Uji Normalitas

\begin{tabular}{|c|c|c|c|c|c|}
\hline \multicolumn{6}{|c|}{ One-Sample Kolmogorov-Smirnov Test } \\
\hline & & Statusgizi & Konsumsipangan & Fasilitasbelajar & Prestasibelajar \\
\hline $\mathrm{N}$ & & 40 & 40 & 40 & 40 \\
\hline \multirow{2}{*}{$\begin{array}{l}\text { Normal } \\
\text { Parameters }{ }^{\mathrm{a}, \mathrm{b}}\end{array}$} & Mean & .3138 & 143.4400 & 75.3000 & 73.5000 \\
\hline & Std. Deviation & 1.70590 & 43.31564 & 10.10001 & 11.39050 \\
\hline \multirow{3}{*}{$\begin{array}{l}\text { Most Extreme } \\
\text { Differences }\end{array}$} & Absolute & .113 & .112 & .080 & .204 \\
\hline & Positive & .059 & .106 & .071 & .109 \\
\hline & Negative & -.113 & -.112 & -.080 & -.204 \\
\hline \multicolumn{2}{|c|}{ Kolmogorov-Smirnov Z } & .716 & .711 & .508 & 1.292 \\
\hline \multicolumn{2}{|c|}{ Asymp. Sig. (2-tailed) } & .685 & .693 & .959 & .071 \\
\hline
\end{tabular}

Berdasarkan tabel 3, menunjukkan data hasil uji normalitas status gizi, terdapat nilai Kolmogorov-Smirnov sebesar 0.716 dengan probabilitas 0.685 . Persyaatan data berdistribusi normal jika probabilitas atau $\mathrm{p}>0.05$ pada uji mormalitas dengan Kolmogrov-Smirnov, artinya data status gizi berdistribusi normal. Hasil uji normalitas konsumsi pangan terdapat nilai Kolmogorov-Smirnov sebesar 0.711dengan probabilitas 0.693 . Hal ini menunjukkan bahwa data konsumsi pangan berdistribusi normal, karena nilai probabilitas $(\mathrm{p}>0.05)$ pada uji normalitas Kolmogorov-Smirnov. Data hasil uji normalitas fasilitas belajar terdapat nilai Kolmogorov-Smirnov sebesar 0.508 dengan probabilitas 0.959 . Hal ini menunjukkan bahwa data fasilitas belajar berdistribusi normal karena nilai probabilitas atau $\mathrm{p}>0.05$ pada uji normalitas dengan Kolmogorov-Smirnov. Sedangkan data hasil uji normalitas prestasi belajar matematika, nilai Kolmogorv-Smirnov sebesar 1.292 dengna probabilitas 0.071. Hal ini membuktikan bahwa datas prestasi belajar matematika berdistribusi normal, dikarenakan nilai probabiitas atau $\mathrm{p}>0.05$ pada uji normalitas dengan KolmogrovSmirnov.

\section{Uji Linearitas}

Uji linearitas digunakan untuk mengetahui dan membuktikan bahwa hubungan antar variabel yang diteliti memiliki hubungan yang linear.Melakukan uji linear, digunakan analisis regresi dengan bantuan SPSS 20. Jika nilai probabilitas $p>0.05$ maka $\mathrm{H}_{0}$ diterima dan $\mathrm{H}_{1}$ ditolak artinya model regresi bersifat linear.

Tabel 4. Ringkasan Uji Linieritas

\begin{tabular}{|c|c|c|c|}
\hline Garis yang Diuji & F & Sig. & Simpulan \\
\hline Y atas X1 & 9,532 & 0,099 & Model regresi berpola linier \\
\hline Y atas X2 & 2,094 & 0,376 & Model regresi berpola linier \\
\hline Y atas X3 & 1,220 & 0,323 & Model regresi berpola linier \\
\hline
\end{tabular}

Berdasarkan tabel 4, menunjukkan hubungan antara status gizi terhadap prestasi belajar matematika anak, dilihat dari nilai $\mathrm{F}$ sebesar 9.532 dengan probabilitas 0.099 . $\mathrm{Hal}$ ini menunjukkan $\mathrm{H}_{0}$ diterima dan $\mathrm{H}_{1}$ ditolak dengan kata lain bahwa garis regresi antara status gizi terhadap prestasi belajar matematika anak adalah linear, dikarenakan $\mathrm{p}>0.05$. Selain ituberdasarkan tabel 4, menunjukkan hubungan antara konsumsi pangan terhadap prestasi belajar matematika anak menghasilkan nilai F sebesar 2.094 dengan probabilitas 0.376 , karena nilai signifikasi $\mathrm{p}>0.05$ maka $\mathrm{H}_{0}$ diterima dan $\mathrm{H}_{1}$ ditolak dengan kata lain bahwa garis regresi pengaruh variabel konsumsi pangan dengan prestasi belajar matematika anak adalah linear.Serta berdasarkan tabel 4 juga, 
menunjukkan hubungan antara fasilitas belajar terhadap prestasi belajar matematika anak menghasilkan nilai $\mathrm{F}$ sebesar 1.220 dengan probabilitas 0.323 , karena nilai signifikasi $\mathrm{p}>0.05$ maka $\mathrm{H}_{0}$ diterima dan $\mathrm{H}_{1}$ ditolak dengan kata lain bahwa garis regresi pengaruh variabel fasilitas belajar dengan prestasi belajar matematika anak adalah linear.

\section{Uji Multikolinearitas}

Uji Multikolinearitas digunakan untuk mendeteksi apakah model regresi mengalami multikolinearitas dengan menggunakan VIF. Jika nilai VIF kurang dari 10 dan angaka tolerance mendekati angka 1 maka tidak terjadi multikolinearitas antara status gizi, konsumsi pangan dan fasilitas belajar.

Tabel 5. Uji Multikolinearitas

\begin{tabular}{lcc}
\hline Variabel Bebas & \multicolumn{2}{c}{ Collinearity } \\
\hline & Tolerance & VIF \\
\hline Status Gizi & 0.769 & 1.301 \\
\hline Konsumsi Pangan & 0.566 & 1.766 \\
\hline Fasilitas Belajar & 0.676 & 1.48 \\
\hline
\end{tabular}

Berdasarkan tabel 5, diperoleh nilai Tolerance status gizi sebesar 0.769 dan VIF sebesar 1.301, untuk nilai tolerance konsumsi pangan sebesar 0.566 dan VIF sebesar 1.766, sedangkan nilai tolerance fasilitas belajar sebesar 0.676 dan VIF sebesar 1.480. Sehingga dapat dinyatakan bahwa status gizi, konsumsi pangan dan fasilitas belajar tidak ada multikolinearitas.

\section{Pengujian Hipotesis}

Analisis korelasi digunakan untuk mencari koefisien korelasi, yang selanjutnya koefisien korelasi tersebut akan digunakan untuk menentukan koefisien regresi. Analisis korelasi menggunakan SPSS 20 sebagai alat bantu dengan hasil sebagai berikut:

Tabel 6. Uji Korelasi antara Status Gizi, Konsumsi Pangan dan Fasilitas Belajar terhadap Prestasi Belajar Matematika Anak.

\begin{tabular}{lcrrr}
\hline \multicolumn{5}{c}{ Model Summary $^{\mathbf{b}}$} \\
\hline Model & $\mathrm{R}$ & R Square & \multicolumn{1}{c}{ Adjusted R Square } & Std. Error of the Estimate \\
\hline 1 & $.830^{\mathrm{a}}$ & .689 & .663 & 6.61234 \\
\hline
\end{tabular}

Tabel 6 menunjukkan bahwa koefisien korelasi ganda antara status gizi, konsumsi pangan, dan fasilitas belajar secara bersama-sama terhadap prestasi belajar matematika anak adalah 0.830, hal ini menunjukkan pengaruh yang kuat. Sedangkan kontribusi atau sumbangan secara simultan variabel status gizi, konsumsi pangan, dan fasilitas belajar terhadap prestasi belajar matematika anak adalah $68.9 \%$ dan $31.1 \%$ dipengaruhi oleh variabel yang lain.

\section{Pengujian Hipotesis Kesatu}

Pengujian hipotesis satu yaitu pengaruh status gizi, konsumsi pangan, dan fasilitas belajar secara bersama-sama terhadap prestasi belajar matematika anak. Hipotesis kesatu dalam penelitian sebagai berikut:

$\mathrm{H}_{0}$ : Tidak terdapat pengaruh status gizi, konsumsi pangan dan fasilitas belajar secara bersama-sama terhadap prestasi belajar matematika anak.

$\mathrm{H}_{1}$ : Terdapat pengaruh status gizi, konsumsi pangan dan fasilitas belajarsecara bersama-sama terhadap prestasi belajar matematika anak. 
Tabel 7. Hasil Uji Signifikan RegresiGanda Status Gizi, Konsumsi Pangan dan Fasilitas Belajar terhadap Prestasi Belajar Matematika Anak

\begin{tabular}{llrrrrr}
\hline \multicolumn{7}{c}{ ANOVA $^{\mathbf{b}}$} \\
\hline \multirow{2}{*}{ Model } & & Sum of Squares & df & Mean Square & F & \multicolumn{1}{c}{ Sig. } \\
\hline \multirow{2}{*}{1} & Regression & 3485.969 & 3 & 1161.990 & 26.576 & $.000^{\mathrm{a}}$ \\
\cline { 2 - 7 } & Residual & 1574.031 & 36 & 43.723 & & \\
\cline { 2 - 7 } & Total & 5060.000 & 39 & & & \\
\hline
\end{tabular}

Tabel 7 menunjukkan bahwa koefisien regresi antara status gizi, konsumsi pangan, dan fasilitas belajar secara bersama-sama terhadap prestasi belajar matematika anak dapat dilihat pada tabel F yaitu 26.576 dengan Sig. $0.000<0.05$. Hal ini dapat disimpulkan terdapat pengaruh status gizi, konsumsi pangan dan fasilitas belajar secara bersama-sama terhadap prestasi belajar matematika anak.

Tabel 8. Uji Signifikasi Pengaruh Status Gizi, Konsumsi Pangan, dan Fasilitas Belajar terhadap Prestasi Belajar Matematika Coefficients $^{\mathrm{a}}$

\begin{tabular}{|c|c|c|c|c|c|c|}
\hline \multirow[b]{2}{*}{ Mod } & & \multicolumn{2}{|c|}{$\begin{array}{c}\text { Unstandardized } \\
\text { Coefficients }\end{array}$} & \multirow{2}{*}{$\begin{array}{c}\text { Standardized } \\
\text { Coefficients } \\
\text { Beta }\end{array}$} & \multirow[b]{2}{*}{$\mathrm{t}$} & \multirow[b]{2}{*}{ Sig. } \\
\hline & & B & Std. Error & & & \\
\hline \multirow[t]{4}{*}{1} & (Constant) & 13.561 & 8.014 & & 1.692 & .099 \\
\hline & Statusgizi & 1.634 & .700 & .248 & 2.335 & .025 \\
\hline & Konsumsipangan & .073 & .032 & .277 & 2.245 & .031 \\
\hline & Fasilitasbelajar & .653 & .128 & .579 & 5.123 & .000 \\
\hline
\end{tabular}

\section{Pengujian Hipotesis Kedua}

Pengujian hipotesis dua yaitu pengaruh status gizi terhadap prestasi bealajar matematika. Hipotesis kedua penelitian ini adalah:

$\mathrm{H}_{0}$ : Tidak terdapat pengaruh status gizi terhadap prestasi belajar matematika.

$\mathrm{H}_{1}$ : Terdapat pengaruh status gizi terhadap prestasi belajar matematika.

Berdasarkan tabel 8, nilai $\mathrm{t}_{0}=2.335$ dan Sig. $=0.025<0.05$. Hal ini menunjukkan bahwa $\mathrm{H}_{0}$ tidak dapat diterima dan $\mathrm{H}_{1}$ diterima, sehingga dapat disimpulkan terdapat pengaruh yang signifikan status gizi terhadap prestasi belajar matematika anak.

\section{Pengujian Hipotesis Ketiga}

Pengujian hipotesis ketiga yaitu pengaruh konsumsi pangan terhadap prestasi belajar matematika. Hipotesis ketiga penelitian ini adalah:

$\mathrm{H}_{0}$ : Tidak terdapat pengaruh konsumsi pangan terhadap prestasi belajar matematika.

$\mathrm{H}_{1}$ : Terdapat pengaruh konsumi pangan terhadap prestasi belajar matematika.

Tabel 8, menjelaskan bahwa nilai $\mathrm{t}_{0}=2.245$ dan Sig. $=0.031<0.05$. Hal ini menunjukkan bahwa $\mathrm{H}_{0}$ tidak dapat diterima dan $\mathrm{H}_{1}$ diterima, sehingga dapat disimpulkan terdapat pengaruh yang signifikan konsumsi pangan terhadap prestasi belajar matematika anak. 


\section{Pegujian Hipotesis Keempat}

Hipotesis keempat yaitu pengaruh fasilitas belajar terhadap prestasi belajar matematika. Hipotesis keempat penelitian ini adalah:

$\mathrm{H}_{0}$ : Tidak terdapat pengaruh fasilitas belajar terhadap prestasi belajar matematika.

$\mathrm{H}_{1}$ : Terdapat pengaruh fasilitas belajar terhadap prestasi belajar matematika.

Tabel 8, menjelaskan bahwa nilai $\mathrm{t}_{0}=2.245$ dan Sig. $=0.000<0.05$. Hal ini menunjukkan bahwa $\mathrm{H}_{0}$ tidak dapat diterima dan $\mathrm{H}_{1}$ diterima, sehingga dapat disimpulkan terdapat pengaruh yang signifikan fasilitas belajar terhadap prestasi belajar matematika anak.

\section{Pembahasan}

1. Pengaruh Status Gizi, Konsumsi Pangan, dan Fasilitas Belajar terhadap Prestasi Belajar Matematika.

Tabel 6,menjelaskan bahwa koefisien korelasi sebesar 0.830 dan koefisien determinasi sebesar $68.9 \%$, hal ini menunjukkan adanya korelasi yang signifikan dan memiliki pengaruh yang kuat terhadap prestasi belajar matematika anak. Mencapai tumbuh kembang yang optimal dibutuhkan zat gizi yang adekuat melalui pemberian makanan yang sesuai dengan tingkat kemampuan konsumsi anak, tepat jumlah (kuantitas) dan tepat mutu (kualitas) oleh karena itu kekurangan dan maupun kelebihan zat gizi, akan menimbulkan, gangguan kesehatan, status gizi maupun tumbuh kembang otaknya. Syah (2003) bahwa faktor yang mempengaruhi prestasi belajar dibagi menjadi faktor internal dan eksternal. Faktor internal adalah semua faktor yang ada dalam diri siswa yang meliputi faktor fisik atau fisiologis dan faktor psikologis (intelegensi, status gizi, bakat, minat, dan sikap) sedangkan faktor eksternal adalah semua factor yang berada di luar siswa yang meliputi faktor lingkungan sosial dan faktor non sosial (faktor perbedaan individual dan faktr pendekatan belajar). Jadi dapat disimpulkan bahwa prestasi belajar matematika anak dapat dipengaruhi oleh status gizi, konsumsi pangan, dan fasilitas belajar.

\section{Pengaruh Status Gizi terhadap Prestasi Belajar Matematika.}

Tabel 8, menjelaskan nilai $\mathrm{t}_{0}=2.335$ dan Sig. $=0.025<0.05$. Hal ini menunjukkan bahwa $\mathrm{H}_{0}$ tidak dapat diterima dan $\mathrm{H}_{1}$ diterima, sehingga dapat disimpulkan terdapat pengaruh yang signifikan status gizi terhadap prestasi belajar matematika anak. Hasil ini sesuai dengan hasil penelitian Brown dan Pollit (1996). menyatakan bahwa pengaruh asupan zat gizi terhadap gangguan perkembangan anak melalui menurunya status gizi. Status gizi yang kurang akan menimbulkan kerusakan otak, sakit dan penurunanpertumbuhan fisik. Ketiga keadaan ini akan berpengaruh terhadap perkembangan intelektual. Gangguan perkembangan yang tidak normal antara lain ditandai dengan lambatnya kematangan sel-sel syaraf, lambatnya gerakan motoric, kurangnya kecerdasan dan lambatnya respon sosial. Menurut Khomsan(2004), status gizi anak mempunyai dampak positif terhadap inteligensinya. Status gizi yang baik jika tidak didukung oleh usaha yang baik untuk belajar tidak akan memperoleh prestasi yang baik.Kecerdasan kognitif seseorang erat kaitannya dengan status gizi seseorang (Hardinsyah, 2007). Gizi kurang dapat mengganggu motivasi anak, kemampuannya untuk berkonsentrasi, dan kesanggupannya untuk belajar. Hal tersebut tentu akan mempengaruhi prestasi belajar anak. Oleh karena itu, dapat disimpulkan prestasi belajar dapat dipengaruhi oleh status gizi anak. 


\section{Pengaruh Konsumsi Pangan terhadap Prestasi Belajar Matematika.}

Tabel 8, diatas menjelaskan bahwa nilai $\mathrm{t}_{0}=2.245$ dan Sig. $=0.031<0.05$. Hal ini menunjukkan bahwa $\mathrm{H}_{0}$ tidak dapat diterima dan $\mathrm{H}_{1}$ diterima, sehingga dapat disimpulkan terdapat pengaruh yang signifikan status gizi terhadap prestasi belajar matematika anak.Konsumsi pangan diperoleh dari tingkat kecukupan energy dan tigkat kecukupan protein. Gibson (2005) menjelaskan bahwa konsumsi pangan yang kurang akan menyebabkan perubahan metabolisme dalam otak, berakibat ketidakmampuan fungsi normal. Keadaan yang lebih berat dan kronis, kekurangan gizi menyebabkan pertumbuhan badan terganggu, badan lebih kecil diikuti dengan ukuran otak yang juga kecil. Jumlah sel dalam otak berkurang dan terjadi ketidakmatangan dan ketidaksempurnaan biokimia dalam otak. Keadaan ini berpengaruh terhadap perkembangan kecerdasan otak. Menurut Khomsan dan Faisal (2008), zat pembangun merupakan unsur protein dan karbohidrat yang sangat penting untuk perkembangan tingkat kecerdasan seseorang. Jadi dapat disimpulkanbahwa prestasi belajar dipengaruhi oleh konsumsi pangan.

\section{Pegaruh Fasilitas Belajar terhadap Prestasi Belajar Matematika.}

Berdasarkan tabel 8, menjelaskan bahwa nilai $\mathrm{t}_{0}=5.123$ dan Sig. $=0.000<0.05$. $\mathrm{Hal}$ ini menunjukkan bahwa $\mathrm{H}_{0}$ tidak dapat diterima dan $\mathrm{H}_{1}$ diterima, sehingga dapat disimpulkan terdapat pengaruh yang signifikan fasilitas belajar terhadap prestasi belajar matematika anak. Tersedianya sarana belajar yang memadai memungkinkan anak dapat belajar dengan baik, sehingga memungkinkan anak mencapai prestasi belajar yang baik. Sebagaimana dikemukan Darman (1984) dalam (Siregar, 2003) bahwa salah satu faktor yang menentukan prestasi belajar adalah adanya fasilitas belajar yaitu perlengkapan belajar. Fasilitas belajar dapat mempengaruhi proses belajar seseorang. Kurangnya fasilitas menyebabkan siswa kurang dapat mengaktualisasikan kemampuan dasar yang dimilikinya, sehingga dapat menimbulkan kegagalan dalam prestasi akademiknya (Gunarsa dan Gunarsa, 2006). Oleh karena itu, prestasi belajar dapat dipengaruhi oleh fasilitas belajar.

\section{PENUTUP}

\section{Simpulan}

Simpuan dari penelitian pengaruh status gizi, konsumsi pangan, dan fasilitas belajar terhadap prestasi belajar matematika anak SDN 09 pagi Jakarta Utara, yaitu:

1. Status gizi, konsumsi pangan, dan fasilitas belajar memiliki pengaruh yang signifikan scara bersama-sama terhadap prestasi belajar matematika anak.

2. Status gizi memiliki pengaruh yang signifikan terhadap prestasi belajar matematika anak.

3. Konsumsi pangan memiliki pengaruh yang signifikan terhadap prestasi belajar matematika anak.

4. Fasilitas belajar memiliki pengaruh yang signifikan terhadap prestasi belajar matematika anak.

\section{Saran}

Konsumsi pangan anak harus selalu diperhatikan setiap hari, agar kebutuhan zat gizi untuk melakukan aktivitas dapat terpenuhi. Orang tua diharapkan dapat memberikan perhatian secara kontinu pada anak dalam belajar. Perhatian tersebut dapat dilakukan orang tua dengan memberikan fasiitas belajar yang memadai bagi anak di rumah. Orang tua juga perlu memotivasi anak agar bersemangat belajar dengan dipenuhinya segala fasilitas belajar. 


\section{DAFTAR PUSTAKA}

Almatsier. 2011. Prinsip Dasar Ilmu Gizi. Jakarta: Gramedia Pustaka Utama.

Brown JL, Pollitt E. 1996. Malnutrition, Poverty and Intellectual Development. Scientific American 38-43.

Fakultas Kesehatan Masyarakat Universitas Indonesia. 2009. Gizi dan Kesehatan Masyarakat. Jakarta: RajaGrafindo Persada.

Gibson. 2005. Principles of Nutritional Assesment. Oxford: University Press.

Gunarsa SD dan Gunarsa YSD. 2006. Psikologi Perkembangan Anak dan Remaja. Jakarta: BPK Gunung Mulia.

Hardiansyah et al. 2002. Modul Ketahanan Pangan 03: Analisis Kebutuhan Konsumsi Pangan. Institut Pertanian Bogor, Pusat Studi Kebijakan Pangan dan Gizi (PSKPG) dan Departemen Pertanian, Pusat Pengembangan Konsumsi Pangan (PPKP) Badan Bimas Ketahanan Pangan.

Hardinsyah. 2007. Inovasi dan Pengembangan Modal Sosial Bagi Peningkatan Kualitas Hidup Manusia dan Pengentasan Kemiskinan. Orasi Ilmiah, Fakultas Ekologi Manusia: Institut Pertanian Bogor.

Hawadi RA. 2001. Psikologi Perkembangan Suatu Pendekatan Sepanjang Rentang Kehidupan, Edisi Kelima. Jakarta: Erlangga.

Harper LJ, Deaton BJ, Driskel JA. 1986. Pangan, Gizi, dan Pertanian (Suhardjo, penerjemah). Jakarta: UI-Press.

Julianto, I. 2010. Rahasia Kecerdasan Anak. Jakarta: PT Kompas Media Nusantara.

Khomsan, A. 2004. Pangan dan Gizi untuk Kualitas Hidup. Jakarta: Grasindo.

Khomsan A. dan Faisal, A. 2008. Sehat Itu Mudah. Jakarta: Mizan.

Nasoetion A. dan Riyadi H. 1994. Gizi Terapan. Departemen Gizi Masyarakat dan Sumberdya keluarga. Fakultas pertanian, Institut Pertanian Bogor.

Purwanto. 2010. Evaluasi Hasil Belajar. Yogyakarta: Pustaka Belajar.

Sardiman AM. 2005. Interaksi dan Motivasi Belajar Mengajar. Jakarta: PT Raja Grafindo Persada.

Siregar. 2003. Pola asuh, tingkat konsumsi pangan, status gizi serta tingkat perkembangan sosial dan emosi anak yang tinggal dipanti asuhan dan keluarga [Skripsi]. Bogor: Fakultas Pertanian, IPB.

Soekirman. 2002. Ilmu Gizi dan Aplikasinya. Jakarta: Dirjen Perguruan Tinggi Depdiknas.

Suhardjo. 1989. Sosio Budaya Gizi. Departemen Pendidikan dan Kebudayaan. Direktorat Jenderal Pendidikan Tinggi Pusat antar Universitas Pangan dan Gizi. Bogor: IPB.

Supariasa. 2004. Penilaian Status Gizi. Jakarta: EGC.

Suryabrata, S. 2005. Psikologi Pendidikan. Jakarta: PT. Raja Grafindo Persada.

Syah, Muhibbin. 2003. Psikologi Belajar. Jakarta: Rajawali Pers.

World Health Organization (WHO). 2007. WHO Expert Committee on Physical Status: the Use and Interpretation of Antrophometry. Geneva: WHO.

Winkel WS. 2005. Psikologi Pengajaran. Jakarta: Grasindo. 